\title{
Fatigue strength evaluation of PPGF35 by energy approach during mechanical tests
}

\author{
Giacomo Risitano, \\ University of Messina, Italy \\ giacomo.risitano@unime.it, bttp://orcid.org/0000-0002-0506-8720
}

\begin{abstract}
Thanks to the progress of research on thermoplastic materials, the properties of composite materials have improved considerably.

The aim of this study is the evaluation of fatigue strength of glass-fibrereinforced polypropylene composite (PPGF35) by applying both the Risitano Thermographic Method (RTM) and the new Static Thermographic Method (STM).
\end{abstract}

KEYWORDs. Glass-fibre-reinforced polypropylene composite; Fatigue assessment; Risitano Thermographic Method; Static Thermographic Method.

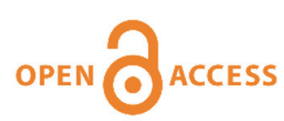

Citation: Risitano, G., Fatigue Strength Evaluation of PPGF35 by Energy Approach During Mechanical Tests, Frattura ed Integrità Strutturale, 59 (2022) 537-548.

Received: 05.10 .2021

Accepted: 19.12 .2021

Published: 01.01.2022

Copyright: (C) 2022 This is an open access article under the terms of the CC-BY 4.0, which permits unrestricted use, distribution, and reproduction in any medium, provided the original author and source are credited.

\section{INTRODUCTION}

7 hanks to the progress of research on thermoplastic materials, the mechanical and thermal properties of composite materials have improved considerably. The improved performance has made these materials more competitive than traditional thermosetting matrix composites, in particular for the automotive companies where they are used for panels, bearings, gears, etc. In fact, until a few years ago, the use of these composite materials was restricted to automotive applications where mechanical requirements had to be limited. Today it is possible to obtain light and low cost components using composites with Short Fibre Reinforced Plastics (SFRP). These materials, filled with glass fibres up to 50\% by mass, are now used for structural components as reported by several papers: Bernasconi et al. [1] worked on fatigue strength of a clutch pedal in short glass fibre reinforced polyamide; Casado et al. [2] wrote about the fatigue failure of short glass fibre for railway track; Sonsino et al. [3] worked on the fatigue design of highly loaded short glass fibre reinforced polyamide parts in engine compartments; Scappatici et al. [4] have optimized the design of horizontal-axis small wind turbines. It must also be considered that the recyclable nature of these materials is clearly an interesting step towards the protection of the natural ecosystem.

Recently, efforts to reduce the weight of automobiles by the increased use of plastics and their composites, have led to a growing interest of short-fibre-reinforced injection-moulded thermoplastics into fatigue-sensitive applications [5, 6].

One of the most important applications of glass reinforced polypropylene is in automotive body panels made by low cost thermoforming techniques. The design of short fibre reinforced plastic components for structural applications requires an accurate knowledge of the several factors affecting the tensile properties and the fatigue lifetime. The tensile strength and 
toughness/impact energy of short fibre reinforced polymer composites would depend on a number of factors such as fibre length, interfacial adhesion and properties of components. Indeed, Fu SY et al [7] studied the effects of PA66/PP ratio on the mechanical properties of short glass fiber reinforced.

The fatigue tests of SFRP materials require even more time consuming than the tests required for metallic materials due to the presence of the viscous behaviour of the matrix which leads to a high accumulation of heat at high test frequencies [3]. In fact, this heat can lead to a change in the mechanical characteristics of the material by altering the test results.

Ferreira et al. [8] obtained the S-N curves of polypropylene/glass-fibre thermoplastic composites produced from a bidirectional woven cloth mixture of $\mathrm{E}$ glass fibres and polypropylene fibres. Esmaeillou et al. [9] performed tension-tension fatigue tests on SFRP composites at different applied maximum stress and analysed the specimens at both microscopic and macroscopic scale. The temperature was measured during cyclic loading using an infrared camera and the progressive loss of stiffness was evaluated during the tests. Moreover, the effects of the frequency and of the mean stress on the fatigue strength were evaluated. An energy-based approach was proposed by Meneghetti and Quaresimin [10] to analyse the fatigue strength of plain and notched specimens made of a short fibre-reinforced plastic weakened by rounded notches.

Toubal et al. [11] used an analytical model based on cumulative damage for predicting the damage evolution in composite materials. Fatigue tests of specimens have been monitored with an infrared thermography system. Belmonte et al. [12] investigated the influence of short fibre volume fraction presentence in PA66 on the damage mode during an uniaxial fatigue test. Wilmes and Hornberger [13] discussed different lifetime estimation methods of different PA66GF35 specimens with different shapes and fibre orientation.

Traditional methods for assessing the fatigue behaviour of materials are time consuming and expensive. For the first time, La Rosa and Risitano [14] have proposed an innovative method for assessing the fatigue of materials, components and mechanical systems: the Risitano Thermographic Method (RTM). Based on the analysis of thermal infrared images, RTM determines the fatigue limit and the Wöhler curve of the material with a short test time passing from long months tests to a few days long tests.

A review of the scientific results in literature, related to the application of the thermographic techniques to composite materials have been presented by Vergani et al. [15].

An innovative method to determinate the fatigue limit during tensile static test has been proposed by Clienti et al. [16] for plastic material and by Risitano and Risitano [17] for metallic material. Clienti et al. [16] suggest that during quasi-static tensile tests the area, where first irreversible plasticization occurred, is detectable by the analysis of the T vs $\sigma$ curve considering the temperature change of the curve slope. This variation identifies the transition zone between thermoelastic and thermoplastic behaviour, or in other words, the beginning of irreversible micro-plasticization. The authors have suggested that in that transition zone, there is the damage limit of material. This damage limit must be understood as the macroscopic stress value that would cause the material to break if subjected to cyclic loading at any load ratio. Then, it is very close to the traditional fatigue limit. This approach, called Static Thermographic Method (STM), correlated the first deviation from linearity of the temperature surface of the material during tensile test to the fatigue limit. This was observed for basalt fibre reinforced composites by Colombo et al. [18], high density polyethylene [19] and glass fibre reinforced composites by Harizi et al. [20] and Crupi et al. [21]. Cucinotta et al. [22] monitored the superficial temperature of high strength concrete specimens subjected to compressive loads, observed a deviation from the linear thermoelastic trend. Santonocito [23] applied the STM for the first time on PA12 specimens obtained through additive manufacturing.

Abello et al. [24] applied the "fast" approach to investigate the evolution of thermomechanical variables during cyclic loadings, to perform a comparison between the cyclic dissipated energy given by thermal and mechanical method and, at last, to investigate the relevancy of predicting the fatigue curve from heat build-up measurements for SFRP materials. Jegou et al. [25] investigated PA66GF50 specimens predicting the fatigue curve from the temperature measurements, finding a very good correlation to a Wöhler curve obtained from classical fatigue measurements. Arif \& al. [26] studied the fatigue damage behaviour of PA66 GF30 monitoring the evolution of dynamic modulus, strain, temperature to evaluate damage increasing during fatigue loading. Kodeeswaran et al. [27] evaluated the fatigue life of the polymer gears at different frequencies observing both thermomechanical and root crack failures. Serrano et al. [28] performed three different test cases to fatigue loading; firstly a dissipated energy approach is applied to the samples and then an energetic approach is used to evaluate quickly the fatigue lifetime. The findings are related to the S-N curve and the authors state that dissipated energy field is not giving full access to "life map" of the component, while the dissipated energy approach seems to be dependent on the local structural conditions of the sample. Marco et al. [29] used the contribution of thermal measurements to locate and follow the failure crack and to provide a validation case for a numerical model for fatigue testing.

Katunin et al. [30] studied the self-heating temperature accompanying the fatigue process of polymeric composites and correlated to structural properties. 
This paper investigates fatigue behaviour for a glass-fibre-reinforced polypropylene composite (PPGF35). The aim of this study is to apply for the first time both the Risitano Thermographic Method [14] and the static thermographic method [16] for the evaluation of the fatigue strength of the composite material PPGF35. The results obtained were then compared with the results obtained using the traditional procedure. Obviously, the analysis took into account that composites have different and more complex fatigue mechanisms than metallic materials.

\section{MATERIAL AND METHODS}

$\mathrm{T}$ he material analysed in this study is a glass-fibre-reinforced polypropylene composite (PPGF35). Dog bone specimens (Fig. 1) were injection moulded (type 1A of the ISO 527-2:1993 standard [31]) with processing conditions based on ISO 294-1:1996 [32] and ISO 1873-2:2007 [33]. The specimens were machined out from injection-moulded plates at orientation angle of $0^{\circ}$. Tab. 1 shows the dimensions of the specimen geometry; also in this case the results are processed with a statistical study on 15 specimens and reporting the average and the standard deviation values.

\begin{tabular}{cccccccc}
\hline $\mathrm{a}$ & $\mathrm{b}$ & $\mathrm{c}$ & $\mathrm{d}$ & $\mathrm{e}$ & $\mathrm{f}$ & $\mathrm{R}$ & $\mathrm{h}$ \\
$30.61 \pm 0.18$ & $30.54 \pm 0.13$ & $169.45 \pm 0.37$ & $9.86 \pm 0.02$ & $19.84 \pm 0.06$ & $3.93 \pm 0.01$ & $25,00 \pm 0.15$ & $83,48 \pm 0.26$ \\
\hline \multicolumn{8}{c}{ Table 1: Dimensions of the specimen in $\mathrm{mm}}$.
\end{tabular}

The tensile tests were carried out using an ITALSIGMA's servo-hydraulic load machine at a crosshead rate equal to 5 $\mathrm{mm} / \mathrm{min}$ with constant temperature and relative humidity $\left(23^{\circ} \mathrm{C}\right.$ and $\left.50 \% \mathrm{RH}\right)$. During all tensile tests, the infrared camera FLIR A40 was used (Fig. 2).

Tab. 2 shows the mechanical properties of the material. In addition, Tab. 3 shows the parameters used for the injection moulding of the sample. Tensile tests were carried out on 15 specimens; the results were processed with a statistical study and report the average and standard deviation of the tensile strength, the elastic modulus, the failure strain and density. This led to a significant number of data for analyses with good repeatability.

\begin{tabular}{cccc}
\hline $\begin{array}{r}\text { Tensile } \\
\text { strength }\end{array}$ & $\begin{array}{c}\text { Elastic } \\
\text { Modulus }\end{array}$ & $\begin{array}{c}\text { Failure } \\
\text { strain }\end{array}$ & Density \\
$\sigma_{R}[\mathrm{MPa}]$ & $\mathrm{E}[\mathrm{MPa}]$ & $\varepsilon_{f}[\%]$ & $\rho\left[\mathrm{kg} / \mathrm{m}^{3}\right]$ \\
$112 \pm 2.3$ & $8915 \pm 314.8$ & $3.4 \pm 0.16$ & $1216 \pm 3.6$ \\
\hline
\end{tabular}

Table 2: Mechanical properties of PPGF35.

\begin{tabular}{lllllll}
\hline $\begin{array}{l}\text { Feeding } \\
\text { temperature }\end{array}$ & $\begin{array}{l}\text { Mass } \\
\text { temperature }\end{array}$ & Back pressure & Holding pressure & $\begin{array}{l}\text { Mould } \\
\text { temperature }\end{array}$ & Screw speed & Flow front speed \\
\hline $40-80^{\circ} \mathrm{C}$ & $230-280^{\circ} \mathrm{C}$ & Low to medium & $30-60 \mathrm{MPa}$ & $30-50{ }^{\circ} \mathrm{C}$ & Low to medium & $100-200 \mathrm{~mm} / \mathrm{s}$ \\
\hline
\end{tabular}

Table 3: Injection moulding parameters.

In addition, 20 specimens were tested with cyclic loads. The specimens have the same geometry (Fig. 1) as the tensile tested specimens and they were made with the same procedure shown in Tab. 3.

A load ratio $\mathrm{R}$ of -0.1 and a test frequency $\mathrm{f}$ of $5 \mathrm{~Hz}$ were used for these cyclic tests. The choice of this test frequency is in order to ensure that the temperatures reached during the cyclic tests do not exceed the glass transition temperature of the polypropylene. Indeed, it was verified that higher test frequencies brought the material to too high temperatures thus invalidating the tests. This is a typical situation for composite materials with a plastic matrix; for this reason, fatigue tests are time-consuming for these materials. 

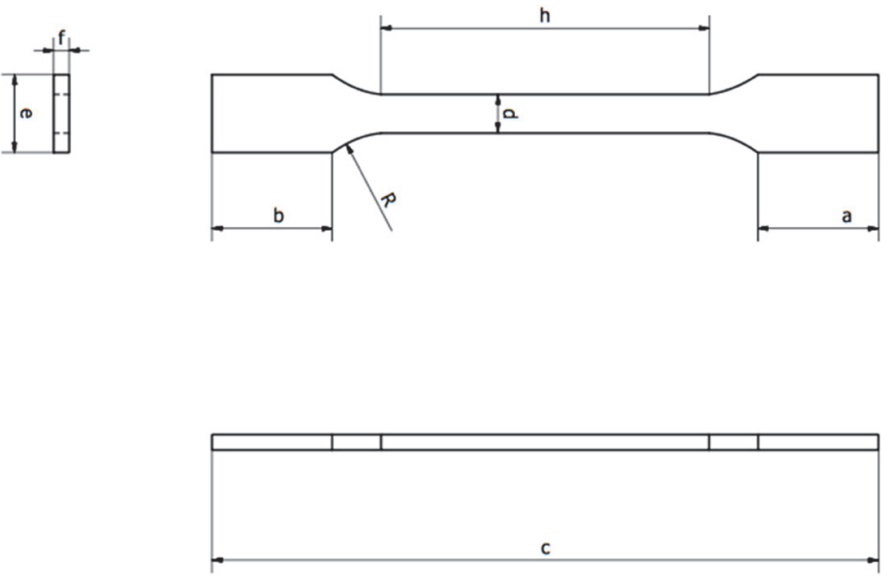

Figure 1: Standard ISO 527-2:1993 specimen.

\section{TEST SETUP}

7 he tests were performed at constant temperature and relative humidity $\left(23{ }^{\circ} \mathrm{C}\right.$ and $50 \%$ RH). As previously mentioned, during all the tests the surface temperature of the specimen was monitored with an IR camera.

In order to determine the Wöhler curve and the fatigue strength, one series of cycling tests (14 specimens) were traditional fatigue tests:

- 3 specimens at maximum stress of $72 \mathrm{MPa}$;

- 3 specimens at maximum stress of $67 \mathrm{MPa}$;

- 3 specimens at maximum stress of $62 \mathrm{MPa}$;

- 3 specimens at maximum stress of $57 \mathrm{MPa}$;

- 2 specimens at maximum stress of $52 \mathrm{MPa}$.

In order to apply the RTM to determine the fatigue strength, 6 step tests were conducted increasing the maximum stress until failure:

- for 3 specimens, four stress steps of 20.000 cycles each were used starting from $52 \mathrm{MPa}$ up to $67 \mathrm{MPa}$;

- for other 3 specimens, eight stress steps of 10.000 cycles each were used starting from $27 \mathrm{MPa}$ up to $67 \mathrm{MPa}$. It is important to remember that the second type of test was adopted to have more data in order to determine the fatigue strength using the RTM [14]. For this reason, during all cycling tests the infrared camera FLIR A40 was used (Fig. 2).

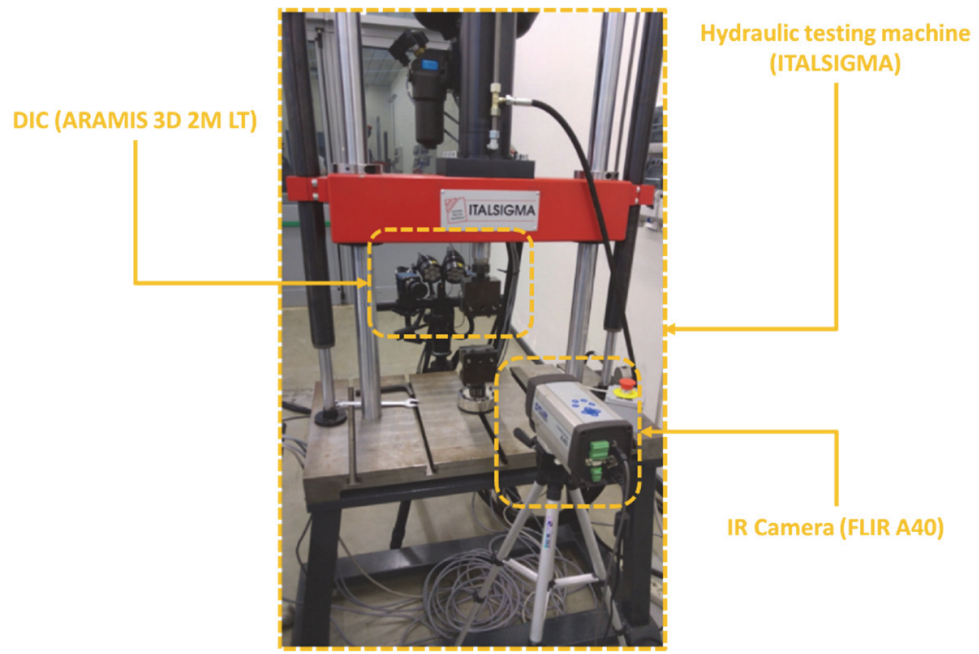

Figure 2: Experimental setup. 


\section{THEORETICAL APPROACH}

A $s$ repeatedly shown in literature and well explained by Clienti et al. [16], during static tests of common engineering materials, the temperature evolution on the specimen surface is characterized by three phases: an initial approximately linear decrease due to the thermoelastic effect (phase 1), then the temperature deviates from linearity until a minimum (phase 2) and a very high further temperature increment until the failure (phase 3).

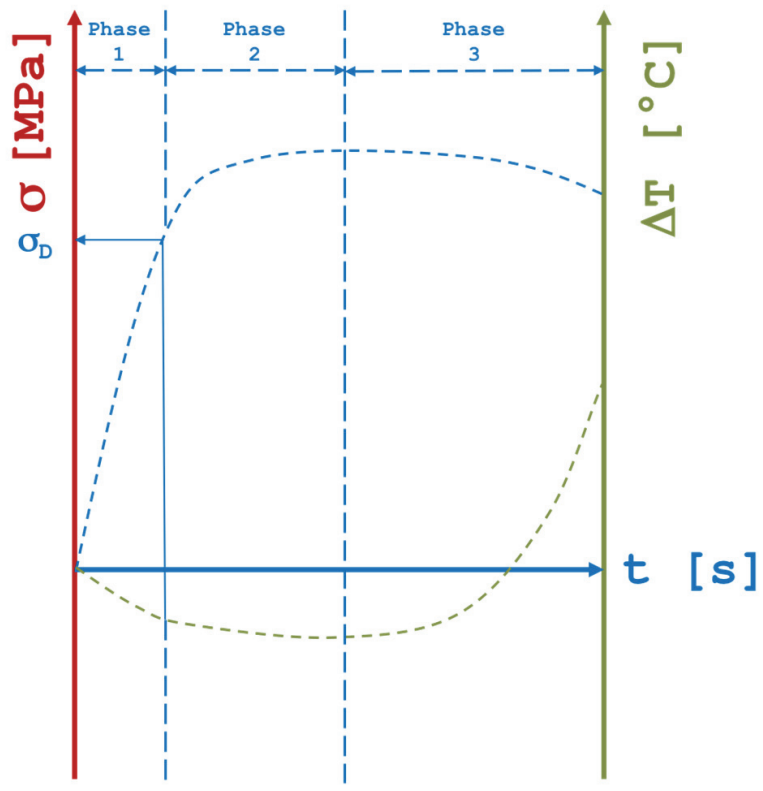

Figure 3: Typical trend of stress and temperature during a static tensile test.

A typical trend of stress and temperature during a static tensile test is shown in Fig. 3. For linear isotropic homogeneous material and in adiabatic condition, the variation of temperature during phase I of the static test for uniaxial stress state is:

$$
\Delta \mathrm{T}=-\frac{\alpha}{\rho \cdot c} T_{0} \cdot \sigma_{1}=-K_{m} T_{0} \cdot \sigma_{1}
$$

where $\mathrm{K}_{\mathrm{m}}$ is the thermoelastic coefficient.

Clienti et al. [16] for the first time correlated the damage stress $\sigma \mathrm{D}$, related to the first deviation from linearity of $\Delta \mathrm{T}$ temperature increment during static test (end of phase I), to the fatigue limit of plastic materials. As reported in [18] "the end of the thermoelastic phase could be related, also for composites, to a stress value $\sigma \mathrm{D}$, which can identify the initiation of a different kind of damage". This method is recognized as Static Thermographic Method (STM).

As repeatedly shown in literature, well explained by La Rosa et al. [14] and in subsequent paper of Corigliano et al. [34], during HCF tests of common engineering materials, when the specimen is cyclically loaded above its fatigue limit, the temperature evolution on the specimen surface is characterized by three phases: an initial rapid increment (phase I), a plateau region (phase II), then a very high further temperature increment until the failure (phase III). The same trend was observed for metals in low cycle fatigue (LCF) by Crupi et al. [35], very high cycle fatigue VHCF regimes by Crupi et al. [36] and for marine welded joints by Corigliano et al. [37]. This method is recognized as "Risitano Thermographic Method" (RTM).

Handa et al. [38] showed that the temperature evolution during the fatigue tests is different for SFRP composite materials. After an initial linear increment (phase I), there is another linear increment with lower slope (phase II). The theoretical $\Delta \mathrm{Td}-$ $\mathrm{N}$ curves, obtained for steel and SFRP composite during constant-amplitude fatigue tests, are shown in Fig. 4.

As showed by Ricotta et al. [39], different approaches were applied to evaluate the fatigue limit of a cold-drawn AISI $304 \mathrm{~L}$ stainless steel in push-pull fatigue tests $(\mathrm{R}=-1)$, and it was found that the fatigue limits estimated by using all the analyzed approaches were in agreement, allowing a rapid assessment of the fatigue limit similar to that evaluated by carrying out a short staircase procedure at 10 million cycles. In particular, by using the RTM and the thermal response in a static tensile test by Static Thermographic Method STM, a difference of, more or less, $12 \%$ and $11 \%$ was observed, respectively. 
The advantages of the STM are the speed of execution and the ease of the test itself. In particular, an STM test for determining the damage limit takes about 5 minutes. The disadvantages are a lower precision of the fatigue strength value (with values always below and, therefore, in safety) and a not easy applicability on materials with high carbon content. Nevertheless, the applicability on plastic and composite materials has repeatedly proved excellent especially considering that the fatigue damage mechanisms are very different for these materials compared to metals.

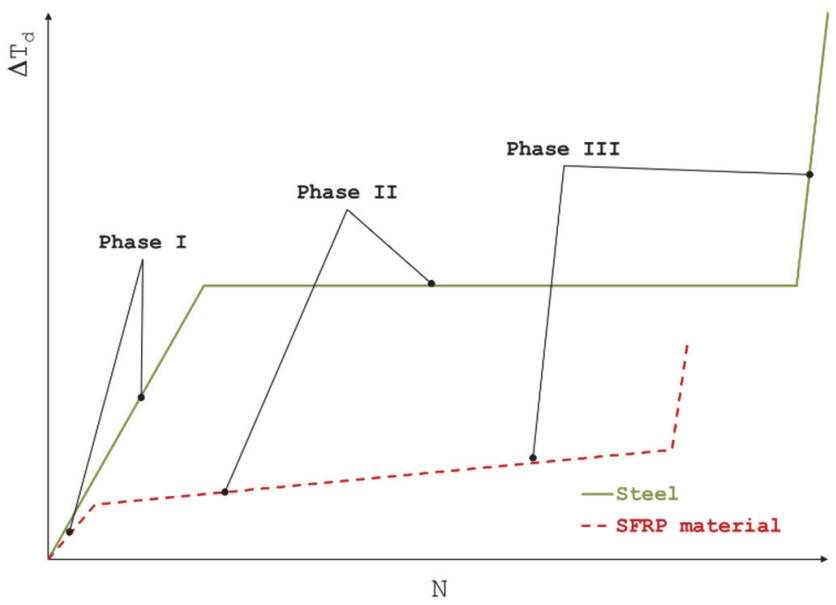

Figure 4: Typical trend of temperature during a fatigue test.

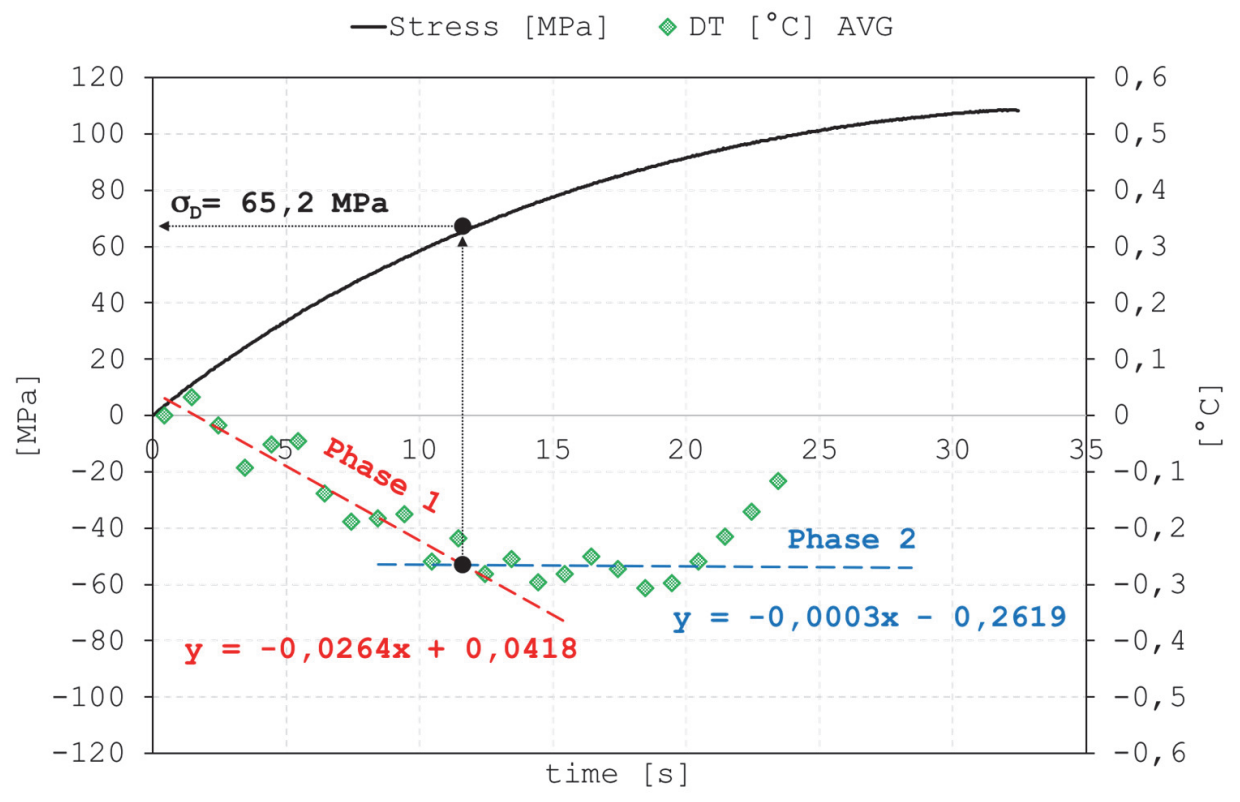

Figure 5: Applied stress and experimental temperature increment during tensile test.

\section{RESULTS AND DISCUSSION}

$\mathrm{D}$ uring tensile tests, the temperature of the specimen surface was detected by means of an IR camera. As example given, Fig. 5 shows the applied stress and the temperature increment $\Delta T$ during a tensile test. In the initial part of the $\Delta \mathrm{T}-\mathrm{t}$ curve, a linear trend is clearly visible in the curve (phase 1) and its slope corresponds to the thermoelastic coefficient $\mathrm{Km}$ of eq. (1). Then, the temperature deviates from linearity (phase 2) presenting a zero derivative flex. It is possible to draw two linear regression lines, one for phase 1 and the other for phase 2 , to determinate the relative equations of the two straight lines. By solving the system of the two equations, it is possible to determine the coordinates of the 
meeting point of the two straight lines and, therefore, the stress value for which there is the transition from phase 1 (thermoelastic phase) to phase 2 (thermoplastic phase). In the specific case, the stress value is $65.2 \mathrm{MPa}$. Obviously, the problem could also be resolved graphically. Similar behaviour can also be seen in the other tensile tests and the value of the fatigue strength determinate by STM on 15 specimens is $63.1 \pm 2.1 \mathrm{MPa}$.

Fatigue tests at constant amplitude values of the stress range were carried out until failure at a load ratio $R=0.1$. Tab. 4 shows the results of the first series of cycling test (fatigue test). The temperature of the specimen surface was detected by an IR camera during each fatigue test. Fig. 6 plots the typical $\Delta \mathrm{T}$ vs $\mathrm{N}$ curve, during a fatigue test at $\sigma \mathrm{max}=67 \mathrm{MPa}$, showing the three phases of temperature evolution as reported by Handa et al. [38]: an initial rapid linear increment (phase I), an another linear increment with lower slope (phase II) and a sudden increase just before the specimen failure (phase III).

\begin{tabular}{cccc}
\hline Test & Maximum Stress $[\mathrm{MPa}]$ & Number of cycles to failure & Run Out \\
1 & 72 & $1.35 \mathrm{E}+04$ & $\mathrm{NO}$ \\
2 & 72 & $2.45 \mathrm{E}+04$ & $\mathrm{NO}$ \\
3 & 72 & $7.34 \mathrm{E}+03$ & $\mathrm{NO}$ \\
4 & 67 & $5.67 \mathrm{E}+04$ & $\mathrm{NO}$ \\
5 & 67 & $8.66 \mathrm{E}+04$ & $\mathrm{NO}$ \\
6 & 67 & $3.52 \mathrm{E}+04$ & $\mathrm{NO}$ \\
7 & 62 & $9.21 \mathrm{E}+05$ & $\mathrm{NO}$ \\
8 & 62 & $6.96 \mathrm{E}+05$ & $\mathrm{NO}$ \\
9 & 62 & $5.10 \mathrm{E}+05$ & $\mathrm{NO}$ \\
10 & 57 & $2.30 \mathrm{E}+06$ & $\mathrm{NO}$ \\
11 & 57 & $7.73 \mathrm{E}+05$ & $\mathrm{NO}$ \\
12 & 57 & $2.48 \mathrm{E}+06$ & YES \\
13 & 52 & $2.36 \mathrm{E}+06$ & YES \\
14 & 52 & $3.25 \mathrm{E}+06$ & YES \\
\hline
\end{tabular}

Table 4: Summary of the first series of cycling tests (fatigue) on 14 specimens.

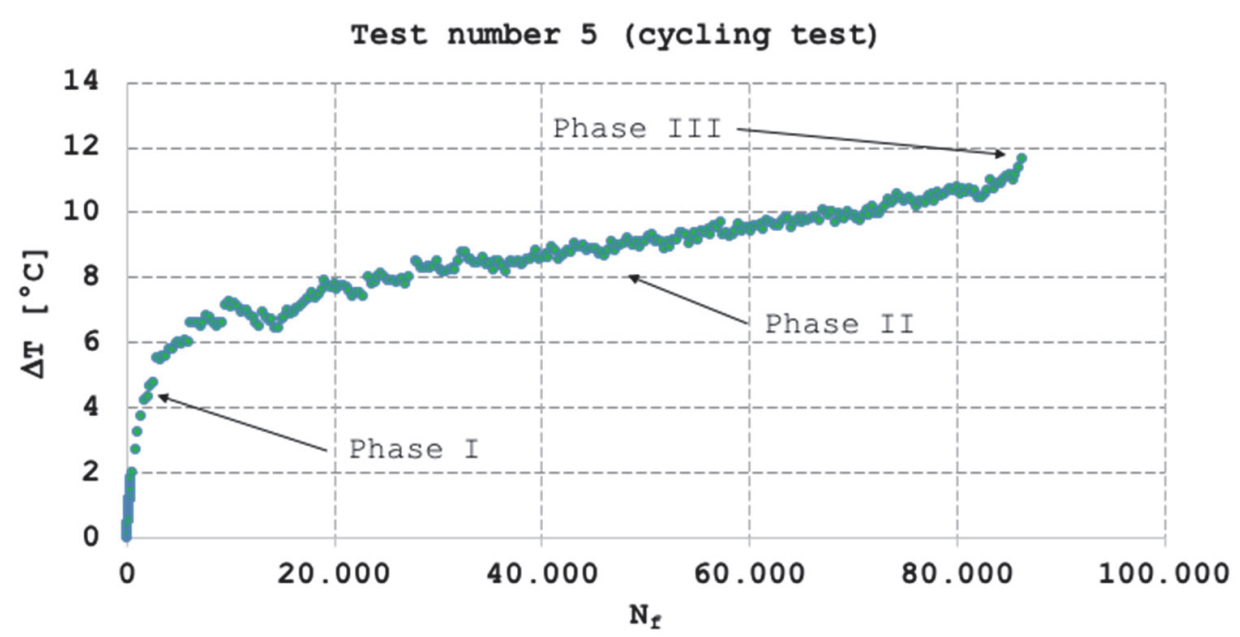

Figure 6: $\Delta \mathrm{T}$ vs $\mathrm{N}$ curve of test number 5 (cycling test). 
Fig. 7 shows the S-N data obtained applying the traditional procedure, based on fatigue tests carried out at constant amplitude of stress ranges of the first series of cycling test. As can be seen from both Tab. 4 and Fig. 7, the results presented a typical dispersion for these materials. In addition, 3 tests were runout: 2 at $52 \mathrm{MPa}$ and 1 at $57 \mathrm{MPa}$. So, if we consider the stress read on the interpolation line of the Wohler Curve at one million cycles (plausible fatigue life for this material), the fatigue strength is more or less $60 \mathrm{MPa}$. Summarizing the results of the fatigue tests, it can be said with good confidence that the fatigue strength is between $52 \mathrm{MPa}$ (runout test) and $60 \mathrm{MPa}\left(1 \cdot 10^{6}\right.$ cycles to failure).

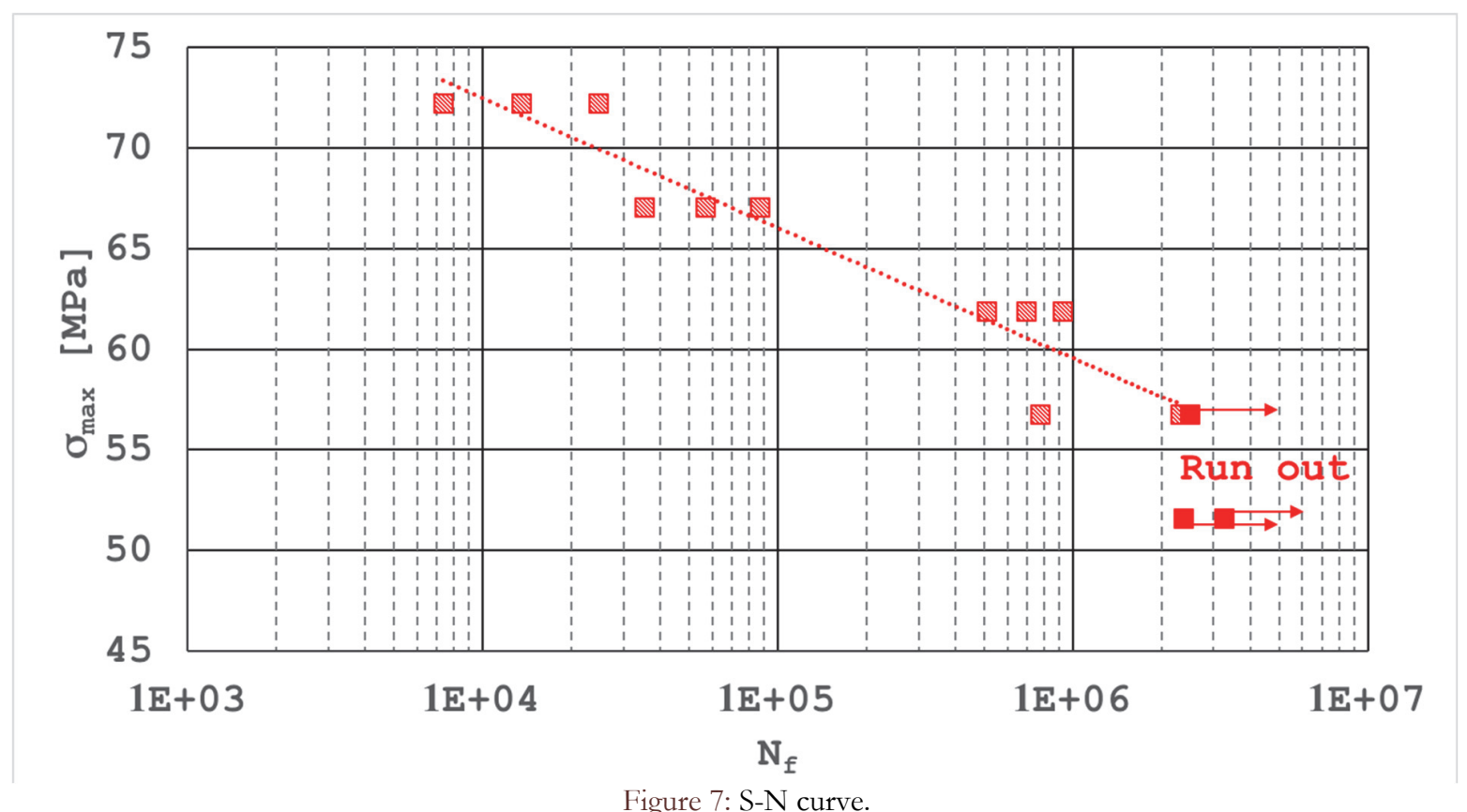

As mentioned previously, 6 specimens have been tested differently to apply the RTM. In fact, a history of increasing block load has been designed for each specimen. Tab. 5 shows the results of the secondo series of cycling test (RTM). Fig. 8 shows the fatigue strength predicted by the RTM using the stabilization temperature applied to all the 20 fatigue tests. As recommended by Curà et al. [40], two distinct linear regressions have been drawn; the x coordinate of the point in common to the two straight lines is the fatigue strength. As it is easy to see, the number of data is really very large with good repeatability. It is very interesting to note that the fatigue strength is $59.7 \mathrm{MPa}$.

In summary, three different methodologies were applied to determine the fatigue strength of PPGF35:

- by traditional procedure - run out (Fig. 7), fatigue strength is determined between $52 \mathrm{MPa}$ ( 3 runout tests) and $60 \mathrm{MPa}\left(1 \cdot 10^{6}\right.$ cycles to failure);

- by Risitano Thermographic Method (Fig. 8), fatigue strength is $59.7 \mathrm{MPa}$;

- by Static Thermographic Method, fatigue strength is $63.1 \pm 2.1 \mathrm{MPa}$.

The values obtained using the different approaches seem to be in good agreement, considering also the dispersion of the value of the fatigue strength of these materials. In fact, it is evident that the results of both the RTM and the STM are within the range determined with the classic method.

However, the most important observation concerns the test time. In fact, to perform the 14 cyclic tests at $5 \mathrm{~Hz}$, the test days consumed were more than 30. To apply RTM with 6 tests at $5 \mathrm{~Hz}$, the test days consumed drop drastically to one and a half. This result confirms the great effectiveness of RTM as an energy method for the determination of fatigue strength compared to traditional methods, totally time consuming. However, the astonishing result is that to perform the 15 tensile tests and obtain a plausible value of the fatigue strength, just over an hour was necessary. 


\begin{tabular}{|c|c|c|c|}
\hline Test & Maximum Stress [MPa] & Number of cycles & Run Out \\
\hline \multirow{4}{*}{15} & 52 & $2.00 \mathrm{E}+04$ & \multirow{4}{*}{$\mathrm{NO}$} \\
\hline & 57 & $2.00 \mathrm{E}+04$ & \\
\hline & 62 & $2.00 \mathrm{E}+04$ & \\
\hline & 67 & $1.65 \mathrm{E}+04$ & \\
\hline \multirow{4}{*}{16} & 52 & $2.00 \mathrm{E}+04$ & \multirow{4}{*}{$\mathrm{NO}$} \\
\hline & 57 & $2.00 \mathrm{E}+04$ & \\
\hline & 62 & $2.00 \mathrm{E}+04$ & \\
\hline & 67 & $5.09 \mathrm{E}+04$ & \\
\hline \multirow{4}{*}{17} & 52 & $2.00 \mathrm{E}+04$ & \multirow{4}{*}{$\mathrm{NO}$} \\
\hline & 57 & $2.00 \mathrm{E}+04$ & \\
\hline & 62 & $2.00 \mathrm{E}+04$ & \\
\hline & 67 & $4.28 \mathrm{E}+04$ & \\
\hline \multirow{9}{*}{18} & 27 & $1.00 \mathrm{E}+04$ & \multirow{9}{*}{$\mathrm{NO}$} \\
\hline & 32 & $1.00 \mathrm{E}+04$ & \\
\hline & 37 & $1.00 \mathrm{E}+04$ & \\
\hline & 42 & $1.00 \mathrm{E}+04$ & \\
\hline & 47 & $1.00 \mathrm{E}+04$ & \\
\hline & 52 & $1.00 \mathrm{E}+04$ & \\
\hline & 57 & $1.00 \mathrm{E}+04$ & \\
\hline & 62 & $1.00 \mathrm{E}+04$ & \\
\hline & 67 & $1.00 \mathrm{E}+04$ & \\
\hline \multirow{9}{*}{19} & 27 & $1.00 \mathrm{E}+04$ & \multirow{9}{*}{$\mathrm{NO}$} \\
\hline & 32 & $1.00 \mathrm{E}+04$ & \\
\hline & 37 & $1.00 \mathrm{E}+04$ & \\
\hline & 42 & $1.00 \mathrm{E}+04$ & \\
\hline & 47 & $1.00 \mathrm{E}+04$ & \\
\hline & 52 & $1.00 \mathrm{E}+04$ & \\
\hline & 57 & $1.00 \mathrm{E}+04$ & \\
\hline & 62 & $1.00 \mathrm{E}+04$ & \\
\hline & 67 & $1.00 \mathrm{E}+04$ & \\
\hline \multirow{9}{*}{20} & 27 & $1.00 \mathrm{E}+04$ & \multirow{9}{*}{$\mathrm{NO}$} \\
\hline & 32 & $1.00 \mathrm{E}+04$ & \\
\hline & 37 & $1.00 \mathrm{E}+04$ & \\
\hline & 42 & $1.00 \mathrm{E}+04$ & \\
\hline & 47 & $1.00 \mathrm{E}+04$ & \\
\hline & 52 & $1.00 \mathrm{E}+04$ & \\
\hline & 57 & $1.00 \mathrm{E}+04$ & \\
\hline & 62 & $1.00 \mathrm{E}+04$ & \\
\hline & 67 & $1.00 \mathrm{E}+04$ & \\
\hline
\end{tabular}

Table 5: Summary of the second series of cycling tests (RTM) on 6 specimens. 


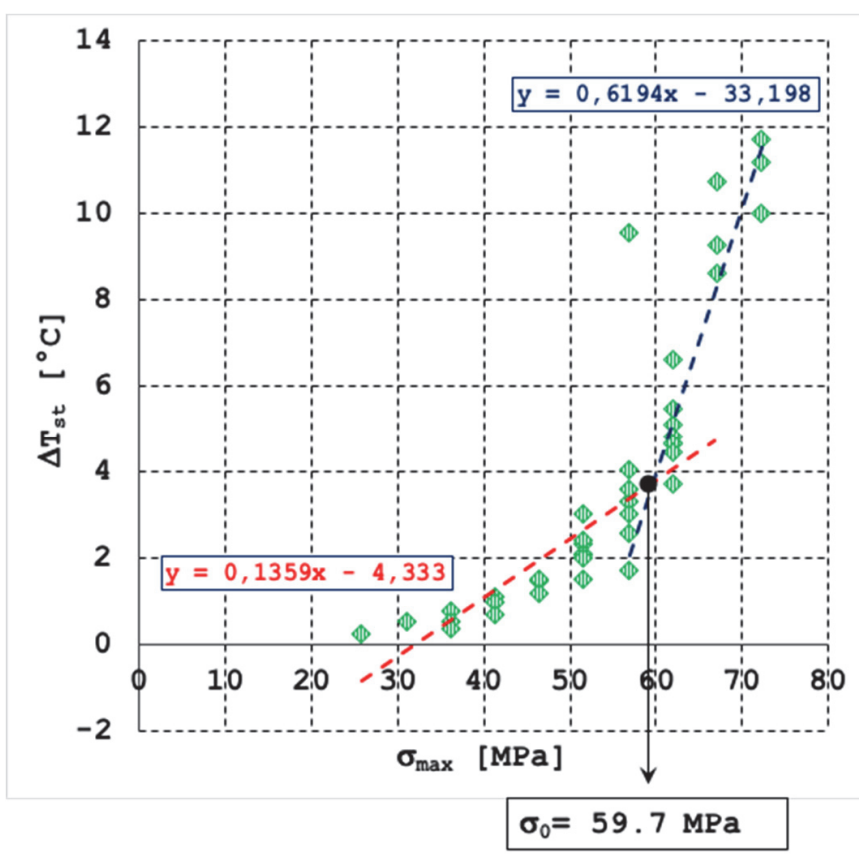

Figure 8: Fatigue strength predicted by the TM.

Traditional Procedure - Run Out [MPa] Risitano Thermographic Method [MPa] Static Thermographic Method [MPa] $52-60$ 59.7 $63.1 \pm 2.1$

Table 6: Fatigue strength predicted by traditional procedure and the experimental values by RTM and STM.

\section{CONCLUSIONS}

$\mathrm{T}$ his paper investigates fatigue behaviour for a glass-fibre-reinforced polypropylene composite (PPGF35). The aim of this study is to apply for the first time both the Risitano Thermographic Method (RTM) [14] and the static Thermographic Method (STM) [16] for the fatigue assessment of PPGF35.

The predictions of the fatigue strength, obtained by means of STM during tensile test and of RTM during cycling tests, were compared with the value obtained by the traditional procedure. The predicted values are in good agreement with the experimental values of fatigue strength:

- by traditional procedure - run out, fatigue strength is determined between $52 \mathrm{MPa}$ and $60 \mathrm{MPa}$;

- by RTM, fatigue strength is $59.7 \mathrm{MPa}$;

- by STM, fatigue strength is $63.1 \pm 2.1 \mathrm{MPa}$.

Finally, it is not indifferent to compare the times necessary for the three types of approaches:

- traditional procedure, the test days consumed were 31 ;

- $\mathrm{RTM}$, the test days consumed were 1.5 ;

- STM, the test hours consumed were 2 .

This enormous time saving does not interfere with the accuracy of the results, especially in a field such as fatigue and composite materials where the dispersion of data is very wide. The results gave interesting information for the development of Risitano Thermographic Method and Static Thermographic Method for the fatigue strength assessment of composite material. Indeed, results of this kind, like others already obtained [16, 17, 21, 37], suggest that STM is an excellent method for estimating the fatigue resistance of materials by consuming a short test time. In particular, such methodologies can quickly provide information on the fatigue behaviour of components and mechanical systems in operation. Methods of this kind would result in a great saving of time and the possibility of having a more detailed design of the mechanical components avoiding approximations on the behaviour of the base material, on the determination of the stresses in exercise, on the real value to be attributed to any notch factors, on the influence of the different technological processes. 


\section{ACKNOWLEDGEMENTS}

7 he research reported in this paper was conducted with the financial support of the Research Project "CERISI" ("Research and Innovation Centre of Excellence for Structure and Infrastructure of large dimensions"), funded by the PON (National Operative Programme) 2007-2013.

\section{REFERENCES}

[1] Bernasconi, A., Davoli, P., Armanni, C. (2010). Fatigue strength of a clutch pedal made of reprocessed short glass fibre reinforced polyamide. Int J Fatigue 32, pp. 100-107. DOI: 10.1016/j.ijfatigue.2009.02.001.

[2] Casado, J.A., Carrascal, I., Polanco, J.A., Gutiérrez-Solana, F. (2006). Fatigue failure of short glass fibre reinforced PA 6.6 structural pieces for railway track fasteners. Eng Fail Anal 13, pp.182-197. DOI: 10.1016/j.engfailanal.2005.01.016.

[3] Sonsino, C.M., Moosbrugger, E. (2008). Fatigue design of highly loaded short-glass-fibre reinforced polyamide parts in engine compartments. Int J Fatigue 30, pp. 1279-1288. DOI: 10.1016/j.ijfatigue.2007.08.017.

[4] Scappatici, L., Bartolini, N., Castellani, F., Astolfi, D., Garinei, A., Pennicchi, M. (2016). Optimizing the design of horizontal-axis small wind turbines: From the laboratory to market. J Wind Eng Ind Aerodyn 154, pp. 58-68. DOI: $10.1016 /$ j.jweia.2016.04.006.

[5] Karger-Kocsis, J., Karger-Kocsis, J. (2012). Structure and Fracture Mechanics of Injection-Molded Composites. Wiley Encycl. Compos., Hoboken, NJ, USA: John Wiley \& Sons, Inc.; DOI: 10.1002/9781118097298.weoc240.

[6] Mortazavian, S., Fatemi, A.(2015). Fatigue behavior and modeling of short fiber reinforced polymer composites: A literature review. Int J Fatigue 70, pp. 297-321. DOI:10.1016/j.ijfatigue.2014.10.005.

[7] Fu, S.Y., Lauke, B., Li, R.K.Y., Mai, Y.W. (2005). Effects of PA6,6/PP ratio on the mechanical properties of short glass fiber reinforced and rubber-toughened polyamide 6,6/polypropylene blends. Compos Part B Eng 37, pp. 182-190. DOI: $10.1016 /$ j.compositesb.2005.05.018.

[8] Ferreira, J.A.M., Costa, J.D.M., Reis, P.N.B. (1999). Static and fatigue behaviour of glass-fibre-reinforced polypropylene composites. Theor Appl Fract Mech 31, pp. 67-74. DOI: 10.1016/S0167-8442(98)00068-8.

[9] Esmaeillou, B., Fitoussi, J., Lucas, A., Tcharkhtchi, A. (2011). Multi-scale experimental analysis of the tension-tension fatigue behavior of a short glass fiber reinforced polyamide composite. Procedia Eng 10, pp. 2117-2122. DOI: $10.1016 /$ j.proeng.2011.04.350.

[10] Meneghetti, G., Quaresimin, M. (2011). Fatigue strength assessment of a short fiber composite based on the specific heat dissipation. Compos Part B Eng 42, pp. 217-25. DOI: 10.1016/j.compositesb.2010.12.002.

[11] Toubal, L., Karama M, Lorrain B. (2006). Damage evolution and infrared thermography in woven composite laminates under fatigue loading. Int J Fatigue 28, pp. 1867-72. DOI: 10.1016/j.ijfatigue.2006.01.013.

[12] Belmonte, E., De Monte, M., Hoffmann, C.J., Quaresimin M. (2017). Damage initiation and evolution in short fiber reinforced polyamide under fatigue loading: Influence of fiber volume fraction. Compos Part B Eng 113, pp. 331-41. DOI: $10.1016 /$ j.compositesb.2017.01.023.

[13] Wilmes, A., Hornberger, K. (2015). Influence of Fiber Orientation and Multiaxiality on the Fatigue Strength of Unnotched Specimens - Lifetime Estimation. Procedia Eng 133, pp. 148-60. DOI: 10.1016/j.proeng.2015.12.642.

[14] La Rosa, G., Risitano, A. (200). Thermographic methodology for rapid determination of the fatigue limit of materials and mechanical components. Int J Fatigue 22, pp. 65-73. DOI:10. 1016/S0142-1123(99)00088-2.

[15] Vergani, L., Colombo, C., Libonati, F. (2014). A review of thermographic techniques for damage investigation in composites. Frat Ed Integrita Strutt 8, pp. 1-12. DOI: 10.3221/IGF-ESIS.27.01.

[16] Clienti, C., Fargione, G., La Rosa, G., Risitano, A., Risitano, G. (2010). A first approach to the analysis of fatigue parameters by thermal variations in static tests on plastics. Eng Fract Mech 77, pp. 2158-2167. DOI: $10.1016 /$ j.engfracmech.2010.04.028.

[17] Risitano, A., Risitano, G. (2013). Determining fatigue limits with thermal analysis of static traction tests. Fatigue Fract Eng Mater Struct 36, pp. 631-639. DOI: 10.1111/ffe.12030.

[18] Colombo, C., Vergani, L., Burman, M. (2012). Static and fatigue characterisation of new basalt fibre reinforced composites. Compos Struct 2012;94, pp. 1165-1174. DOI: 10.1016/j.compstruct.2011.10.007.

[19] Risitano, G., Guglielmino, E., Santonocito, D. (2018). Evaluation of mechanical properties of polyethylene for pipes by energy approach during tensile and fatigue tests. Procedia Struct. Integr., 13, 1663-1669.

DOI: $10.1016 /$ j.prostr.2018.12.348. 
[20] Harizi, W., Chaki, S., Bourse, G., Ourak, M. (2014). Mechanical damage assessment of Glass Fiber-Reinforced Polymer composites using passive infrared thermography. Compos Part B Eng 59, pp. 74-79.

DOI: 10.1016/j.compositesb.2013.11.021.

[21] Crupi, V., Guglielmino, E., Risitano, G., Tavilla, F. (2015). Experimental analyses of SFRP material under static and fatigue loading by means of thermographic and DIC techniques. Compos Part B Eng 77, pp. 268-277.

DOI: 10.1016/j.compositesb.2015.03.052.

[22] Cucinotta, F., D’Aveni, A., Guglielmino, E., Risitano, A., Risitano, G., Santonocito, D. (2021)- Thermal emission analysis to predict damage in specimens of high strength concrete. Frat Ed Integrita Strutt 15, pp. 258-270.

DOI: 10.3221/IGF-ESIS.55.19.

[23] Santonocito, D. (2020). Evaluation of fatigue properties of 3D-printed Polyamide-12 by means of energy approach during tensile tests. Procedia Struct Integr 25, pp. 355-363. DOI: 10.1016/j.prostr.2020.04.040.

[24] Abello, L.S., Marco, Y., Le Saux, V., Robert, G., Charrier, P. (2013). Fast Prediction of the Fatigue Behavior of Short Fiber Reinforced Thermoplastics from Heat Build-up Measurements. Procedia Eng 66, pp. 737-745.

DOI: 10.1016/j.proeng.2013.12.127.

[25]Jegou, L., Marco, Y., Le Saux, V., Calloch, S. (2013). Fast prediction of the Wöhler curve from heat build-up measurements on Short Fiber Reinforced Plastic. Int J Fatigue 47, pp. 259-267. DOI: 10.1016/j.ijfatigue.2012.09.007.

[26] Arif, M.F., Saintier, N., Meraghni, F., Fitoussi, J., Chemisky, Y., Robert, G. (2014). Multiscale fatigue damage characterization in short glass fiber reinforced polyamide-66. Compos Part B Eng 61, pp. 55-65.

DOI: 10.1016/j.compositesb.2014.01.019.

[27] Kodeeswaran, M., Verma, A., Suresh, R., Senthilvelan, S. (2017)- Effects of frequency on hysteretic heating and fatigue life of unreinforced injection molded polyamide 66 spur gears. Proc Inst Mech Eng Part L J Mater Des Appl 146442071770217. DOI: $10.1177 / 1464420717702176$.

[28] Serrano, L., Marco, Y., Le Saux, V., Robert, G., Charrier, P. (2017). Fast prediction of the fatigue behavior of shortfiber-reinforced thermoplastics based on heat build-up measurements: application to heterogeneous cases. Contin Mech Thermodyn, pp. 1-21. DOI: 10.1007/s00161-017-0561-2.

[29] Marco, Y., Le Saux, V., Jégou, L., Launay, A., Serrano, L., Raoult, I., (2014). Dissipation analysis in SFRP structural samples: Thermomechanical analysis and comparison to numerical simulations. Int J Fatigue 67, pp. 142-150. DOI: 10.1016/j.ijfatigue.2014.02.004.

[30] Katunin, A., Wronkowicz, A., Bilewicz, M., Wachla, D. (2017). Criticality of self-heating in degradation processes of polymeric composites subjected to cyclic loading: A multiphysical approach. Arch Civ Mech Eng 17, pp. 806-815. DOI: $10.1016 /$ j.acme.2017.03.003.

[31] ISO 527-2:1993. Plastics — Determination of tensile properties — Part 2: Test conditions for moulding and extrusion plastics.

[32] ISO 294-1:1996. Plastics — Injection moulding of test specimens of thermoplastic materials — Part 1: General principles, and moulding of multipurpose and bar test specimens.

[33] ISO 1873-2:2007. Plastics — Polypropylene (PP) moulding and extrusion materials — Part 2: Preparation of test specimens and determination of properties

[34] Corigliano, P., Cucinotta, F., Guglielmino, E., Risitano, G., Santonocito, D. (2020). Fatigue assessment of a marine structural steel and comparison with Thermographic Method and Static Thermographic Method. Fatigue Fract Eng Mater Struct 43, pp. 734-43. DOI: 10.1111/ffe.13158.

[35] Crupi, V., Chiofalo, G., Guglielmino, E. (2011). Infrared investigations for the analysis of low cycle fatigue processes in carbon steels. Proc Inst Mech Eng Part C J Mech Eng Sci 225, pp. 833-842. DOI: 10.1243/09544062JMES2324.

[36] Crupi, V., Epasto, G., Guglielmino, E., Risitano, G. (2015). Thermographic method for very high cycle fatigue design in transportation engineering. Proc Inst Mech Eng Part C J Mech Eng Sci ;229, pp. 1260-1270. DOI: $10.1177 / 0954406214562463$.

[37] Corigliano, P., Epasto, G., Guglielmino, E., Risitano, G. (2017). Fatigue analysis of marine welded joints by means of DIC and IR images during static and fatigue tests. Eng Fract Mech 183, pp. 26-38. DOI: 10.1016/j.engfracmech.2017.06.012.

[38] Handa, K., Kato, A., Narisawa, I. (1999). Fatigue characteristics of a glass-fiber-reinforced polyamide. J Appl Polym Sci 72, pp. 1783-93. DOI: 10.1002/(SICI)1097-4628(19990624)72:13<1783::AID-APP14>3.0.CO;2-B.

[39] Ricotta, M., Menegehtti, G., Atzori, B., Risitano, G. and Risitano, A. (2019). Comparison of Experimental Thermal Methods for the Fatigue Limit Evaluation of a Stainless Steel. Metals 9(6), pp. 677. DOI: 10.3390/met9060677

[40] Curà, F., Curti, G., Sesana, R. (2005). A new iteration method for the thermographic determination of fatigue limit in steels. Int J Fatigue 27, pp. 453-459. DOI: 10.1016/j.ijfatigue.2003.12.009. 